\title{
ADRENAL STEROID INHIBITION OF VASOPRESSIN RELEASE FROM THE NEUROHYPOPHYSIS OF NORMAL SUBJECTS AND PATIENTS WITH ADDISON'S DISEASE *
}

\author{
By JOSEPH F. DINGMAN ANd RENE H. DESPOINTES †
}

\author{
(From the Endocrine Unit of the Department of Medicine, Tulane Medical School and Charity \\ Hospital, New Orleans, La., and the Departments of Medicine, Peter Bent Brigham \\ Hospital and Harvard Medical School, Boston, Mass.)
}

(Submitted for publication March 21, 1960; accepted August 3, 1960)

There is a large body of evidence to indicate that adrenal steroids decrease distal renal tubular reabsorption of water. A popular view is that this effect may be due to antagonism of the action of vasopressin on the renal tubules (1), but others (2) have postulated that corticoids may exert a direct effect on permeability of the renal tubular cells to water. Recent studies in patients with combined anterior and posterior pituitary insufficiency (3) suggested that adrenal steroids increase free water excretion by suppressing release of vasopressin from hypothalamic portions of the neurohypophysis. Further investigation of this preliminary hypothesis in normal subjects and in patients with Addison's disease forms the basis of this report. ${ }^{1}$

\section{MATERIALS AND METHODS}

Studies of water excretion were performed in 8 individuals with apparently normal adrenal and pituitary function and in 3 patients with Addison's disease. Fluids were withheld after 10 p.m. and all subjects abstained from smoking on the morning of study. Each subject was given a light breakfast including $90 \mathrm{ml}$ of fruit juice at 7 a.m., followed by 1.0 to $1.5 \mathrm{~L}$ tap water by mouth at about 8 a.m. Three of the normal subjects (depicted in Figures 1 and 3) were laboratory personnel who continued their duties throughout the study and collected voided urine specimens at 15 -minute intervals until diuresis subsided.

The remaining normal subjects and the 3 patients were recumbent during study and maintained in a constant state of hydration by administration of tap water orally or of 5 per cent dextrose and water intravenously at a rate equal to urine flow. Urine was collected at 15

* Supported in part by grants from the National Heart Institute ( $\mathrm{H} 2106$ and $\mathrm{H} 2850$ ), the Louisiana Heart Association, and the Upjohn Company.

$\uparrow$ Research assistant on Grant H2106, National Heart Institute, Bethesda, Md.

1 Portions of these studies have been reported previously (4-7). to 30 minute intervals by spontaneous voiding in 5 subjects and through an indwelling urethral catheter in 3 .

The effect of adrenal steroids on the antidiuretic response to nicotine was evaluated in all subjects. Nicotine was administered by vigorous inhalation of cigarette smoke in 3 normal subjects and by intravenous infusion of solutions of nicotine salicylate (8) or nicotine bitartrate 2 in the remainder. Some subjects subsequently received Pitressin 3 (vasopressin) and 3 per cent

TABLE I

Effect of nicotine on renal function in normal subject (P.B.) and the action of adrenal steroids thereon *

\begin{tabular}{|c|c|c|c|c|}
\hline Study & $\mathrm{U}_{\text {osm }} \dagger$ & $\mathrm{C}_{\mathrm{H}_{2} \mathrm{O}} \dagger$ & $C_{o s m} \ddagger$ & $C_{\text {er }} \ddagger$ \\
\hline Controls & $\mathrm{mOsm} / \mathrm{kg}$ & $\mathrm{ml} / \mathrm{min}$ & $\mathrm{ml} / \mathrm{min}$ & $\mathrm{ml} / \mathrm{min}$ \\
\hline $\begin{array}{l}\text { I\$ } \\
\text { II }\end{array}$ & $\begin{array}{l}83 \\
77\end{array}$ & $\begin{array}{l}7.4 \\
8.7\end{array}$ & $\begin{array}{l}3.2 \\
3.0\end{array}$ & $\begin{array}{l}132 \\
127\end{array}$ \\
\hline $\begin{array}{c}\text { Nic. } 3.5 \| \\
4.0 \\
5.0\end{array}$ & $\begin{array}{l}214 \\
243 \\
488\end{array}$ & $\begin{array}{r}1.7 \\
0.4 \\
-1.4\end{array}$ & $\begin{array}{l}5.9 \\
3.9 \\
3.8\end{array}$ & $\begin{array}{l}133 \\
130 \\
115\end{array}$ \\
\hline $\mathrm{F} 1-\mathrm{F} \rrbracket$ & 44 & 15.3 & 2.2 & 131 \\
\hline Nic. $3.0 \|$ & $\begin{array}{r}45 \\
178\end{array}$ & $\begin{array}{r}13.3 \\
2.1\end{array}$ & $\begin{array}{l}3.1 \\
3.2\end{array}$ & $\begin{array}{l}129 \\
120\end{array}$ \\
\hline $\mathrm{DCA}^{* *} \S$ & 77 & 8.8 & 3.1 & 123 \\
\hline $\begin{array}{c}\text { Nic. } 3.0 \| \\
4.0 \\
4.5\end{array}$ & $\begin{array}{r}75 \\
112 \\
86\end{array}$ & $\begin{array}{r}10.0 \\
8.6 \\
9.0\end{array}$ & $\begin{array}{l}3.7 \\
4.2 \\
3.6\end{array}$ & $\begin{array}{l}120 \\
119 \\
115\end{array}$ \\
\hline
\end{tabular}

* Constant water load of $1.0 \mathrm{~L}$ maintained throughout each study.

$\dagger$ Minimum $\mathrm{U}_{\mathrm{osm}}$ and maximum $\mathrm{C}_{\mathrm{H}_{2} \mathrm{O}}$ during water diuresis; maximum $U_{\text {osm }}$ and minimum $\mathrm{C}_{\mathrm{H}_{2} \mathrm{O}}$ following administration of nicotine.

$\ddagger$ Mean values for entire periods of water diuresis and of nicotine antidiuresis.

\$ Values observed during water diuresis.

II Milligrams of nicotine i.v.

T $1.0 \mathrm{mg}$ fluorocortisol by mouth every 6 hours for 2 days prior to study.

** $10 \mathrm{mg}$ DCA i.m. 12 hours before and $5 \mathrm{mg} 2$ hours prior to hydration.

2 Supplied through the kindness of Dr. R. C. Hockett, Tobacco Industry Research Committee, New York, N. Y.

${ }^{3}$ Supplied through the courtesy of Dr. J. E. Gajewski, Parke, Davis \& Co., Detroit, Mich. 


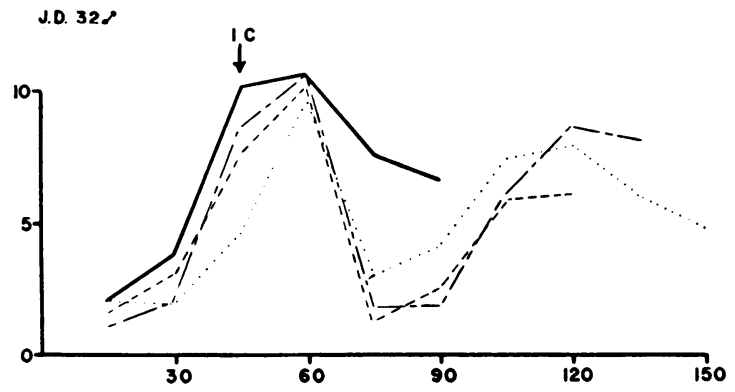

\section{Urine flow} ml./min.

N.A. 308

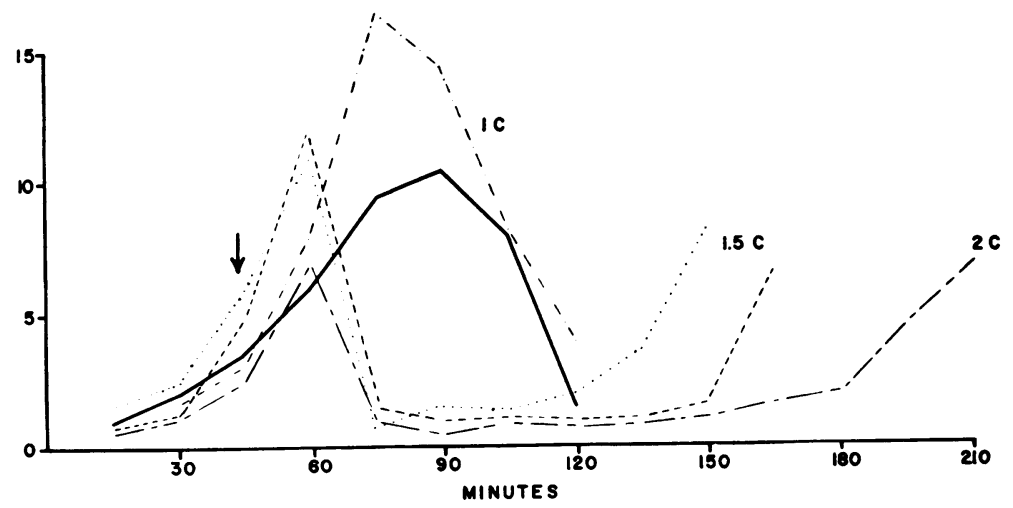

Fig. 1. Antidiuretic response to Cigarette smoking in two Normal subjects. $1.0 \mathrm{~L}$ water imbibed at zero time. Both subjects smoked the designated number of cigarettes (C) at 45 minutes, as indicated by the arrows. The solid line depicts the curve of water diuresis in one control study.

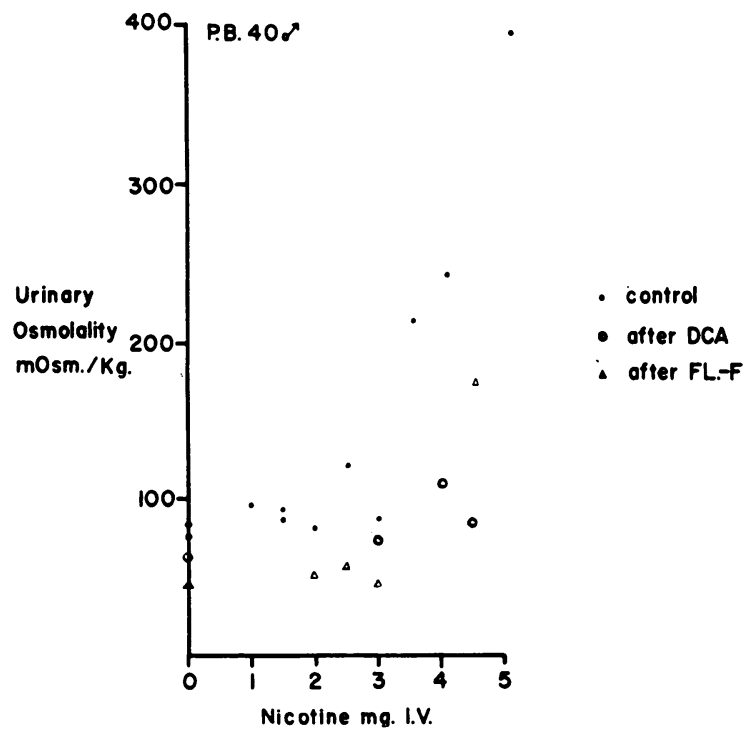

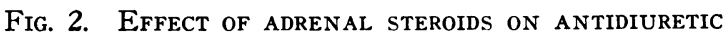
RESPONSE to NICOTINE IN A NORMAL SUBject. Studies performed during sustained hydration of $1.0 \mathrm{~L}$. Data obtained from two separate control studies and one study each with intramuscular desoxycorticosterone acetate (DCA) and oral fluorocortisol (Fl-F). Points at zero
$\mathrm{NaCl}$ solution intravenously according to a described technic (8).

Urinary and serum concentrations of $\mathrm{Na}$ and $\mathrm{K}$ were measured with a Baird flame photometer, total solute concentration by freezing point depression with a Fiske osmometer, and creatinine by a modification of the Jaffé reaction $(9)$. Free water clearance $\left(\mathrm{C}_{\mathrm{H}_{2} \mathrm{O}}\right)$ and osmolal clearance $\left(\mathrm{C}_{\mathrm{osm}}\right)$ were calculated using the formulas of Wesson and Anslow (10). The renal tubular action of endogenous and exogenous vasopressin was estimated from acute changes in urinary osmolality $\left(\mathrm{U}_{\mathrm{osm}}\right.$ ) and $\mathrm{C}_{\mathrm{H}_{2} \mathrm{O}}(8)$. The duration of the antidiuretic response (i.e., interval from injection of vasopressin or onset of endogenous vasopressin antidiuresis to return of $\mathrm{C}_{\mathrm{H}_{2} \mathrm{O}}$ and $\mathrm{U}_{\mathrm{osm}}$ to pre-injection levels) was also utilized as an index of the renal response to vasopressin and of the magnitude of endogenous vasopressin release. ${ }^{4}$

The Addisonian patients had been treated with $25 \mathrm{mg}$ of cortisone acetate by mouth daily, which was with-

4 The duration of antidiuresis has been shown to bear a linear relationship to the log-dose of vasopressin (11), which provides a means of quantitating vasopressin release and assessing the renal effects of the hormone.

on the horizontal scale represent minimum $\mathrm{U}_{\mathrm{osm}}$ observed prior to administration of nicotine intravenously. 


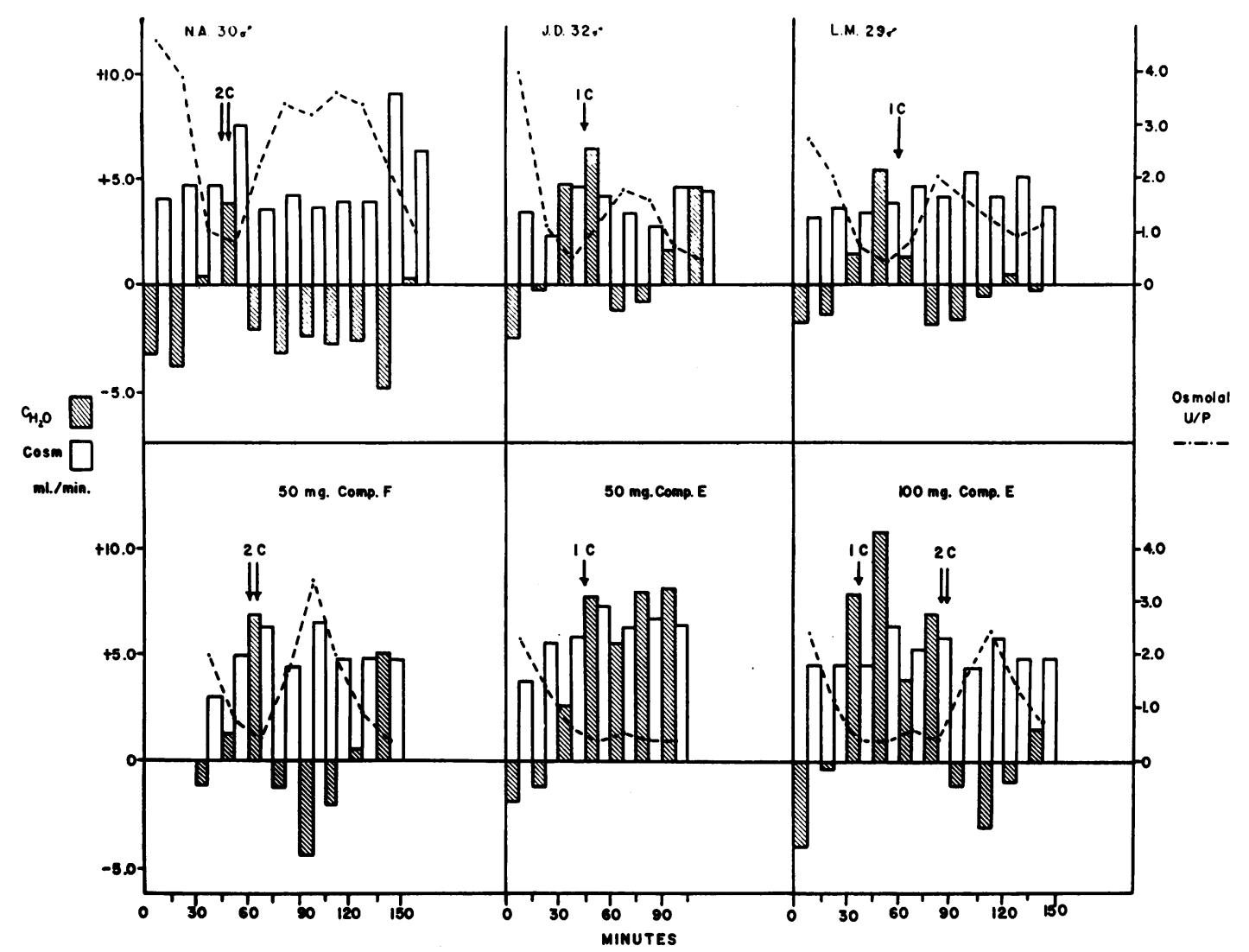

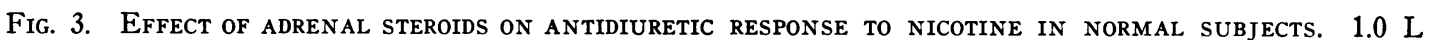
water imbibed at zero time. Steroids administered orally 2 hours prior to study.

held as specified. Two patients required monthly injections of desoxycorticosterone trimethylacetate in doses of 37.5 and $50 \mathrm{mg}$, respectively, to maintain normal salt balance, but the third patient was maintained in good health with cortisone and a liberal salt intake only.

\section{RESULTS}

\section{Reproducibility of the antidiuretic effect of} nicotine. The antidiuretic effect of nicotine (cigarette smoking) was found to be fairly reproducible in two normal subjects (Figure 1) and, in one subject so studied, the duration of antidiuresis appeared to be related to the dose of nicotine. A third normal subject received repeated injections of nicotine intravenously at increasing dose levels in two control studies performed during constant water diuresis (control studies, Figure 2 and Table I). Although this subject was a "heavy" smoker and had an unusually high threshold for nicotine antidiuresis, the magnitude of the antidiuretic response showed a close relationship to the administered dose of nicotine. A slight to moderate increase in $\mathrm{C}_{\text {osm }}$ and no change in creatinine clearance, $\left(\mathrm{C}_{\mathrm{cr}}\right)$, except for a slight fall with $5.0 \mathrm{mg}$ nicotine, were observed during the periods of antidiuresis (Table I).

Approximately equal antidiuretic responses to repeated injections of $1.5 \mathrm{mg}$ of nicotine were observed in one patient with Addison's disease, and $5 \mathrm{mg}$ Regitine (phentolamine) administered intravenously several minutes prior to one injection, did not alter the antidiuretic effect in any way.

2. Effect of glucocorticoids in normal subjects. Cortisone, cortisol and prednisolone administered orally 1 to 2 hours prior to standard hydration (Figures 3 and 4 ) or intravenously during sustained diuresis (Figures 5 and 6) resulted in suppression or complete inhibition of the antidiuretic response to previously effective doses of nicotine in each of six normal subjects. The antidiuretic effects of vasopressin and hypertonic saline were not similarly influenced by these steroids (Figures 5 and 6 ). 


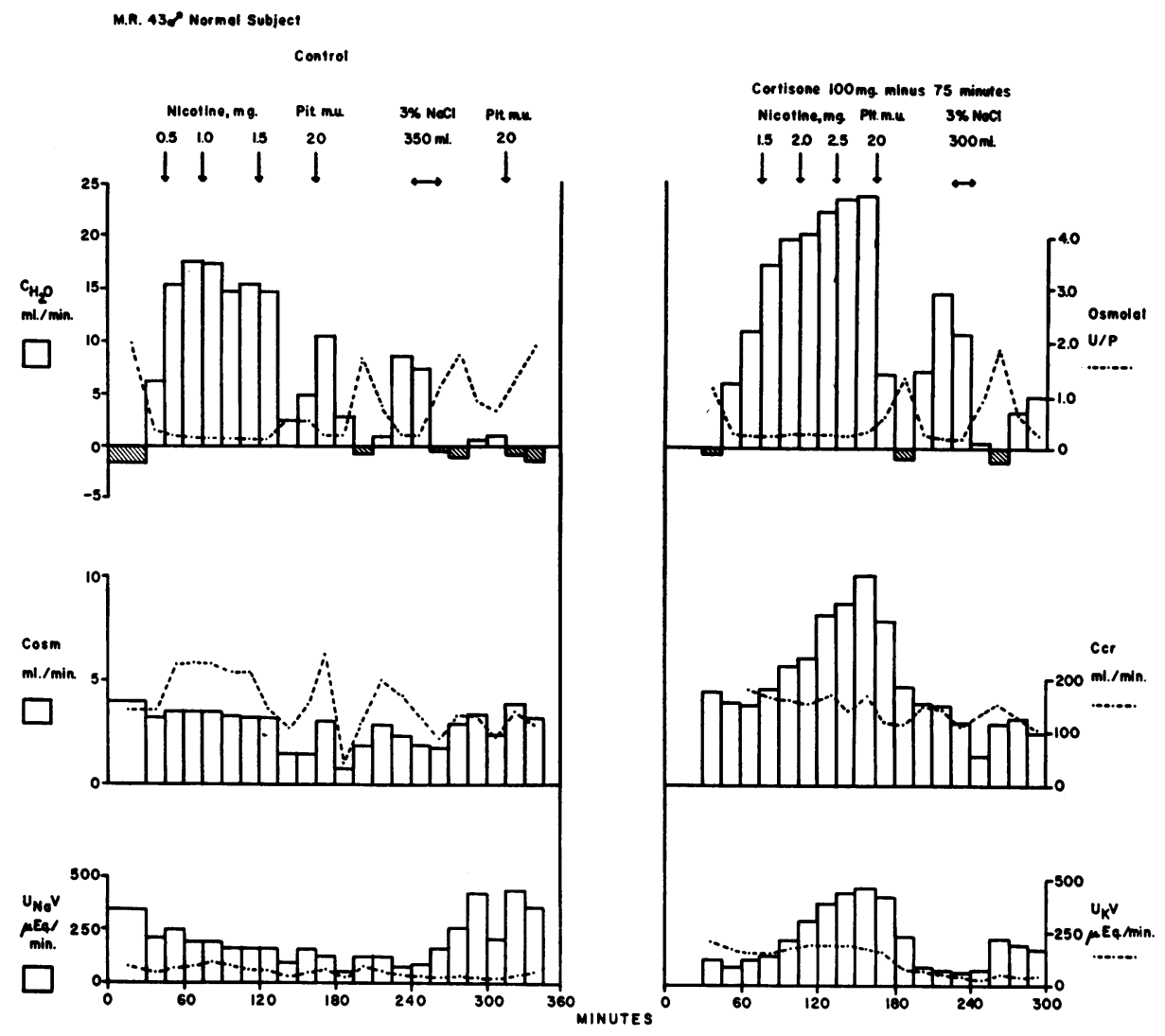

Fig. 4. EfFect of Cortisone on NeUrohypophyseal function. Sustained hydration of $1.5 \mathrm{~L} ;$ Pit.mU. $=$ milliunits vasopressin $($ Pitressin $)$ i.v.

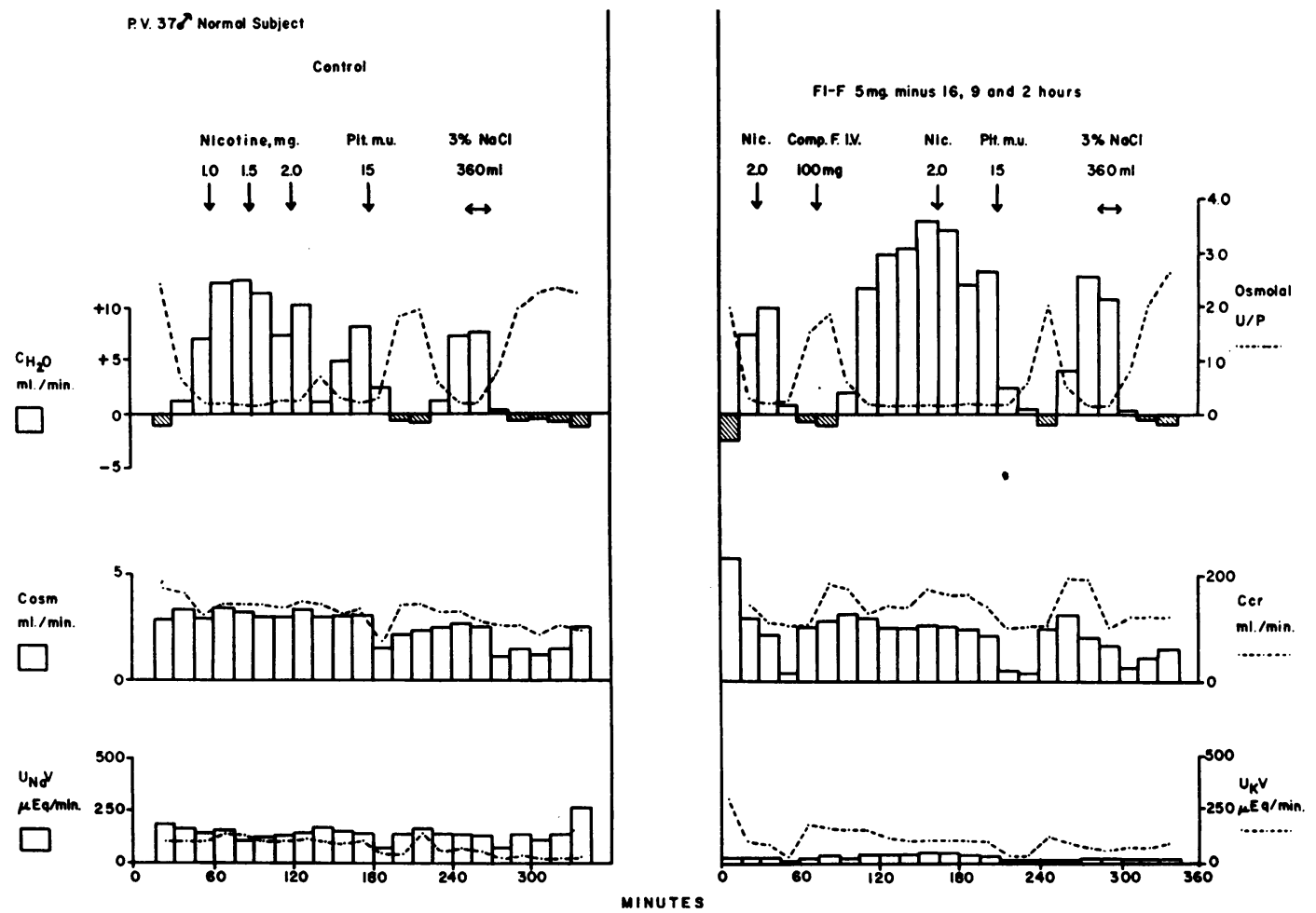

Fig. 5. EfFect of atrfinal steroids on Neurohypophyseal. Function. Sustained hydration of $1.3 \mathrm{~L}$. 
The inhibitory effect of glucocorticoids on nicotine antidiuresis was frequently preceded by and associated with increases in peak $\mathrm{C}_{\mathrm{H}_{2} \mathrm{O}}$ and concomitant decreases in minimum $\mathrm{U}_{\mathrm{osm}}$, indicative of enhanced water diuresis despite conditions of constant hydration.

There were only slight changes observed in $\mathrm{C}_{\text {osm }}$ during these same periods in three subjects (Figure 3), but in one (M.R., Figure 4), a marked increase in $\mathrm{C}_{\mathrm{osm}}$ accompanied the profuse free water diuresis. In the subjects given steroids intravenously (Figures 5 and 6 ), the depressed rates of $\mathrm{Na}$ and total solute excretion resulting from previous $\mathrm{Na}$-retaining steroid therapy were not altered following glucocorticoid administration, yet enhanced $\mathrm{C}_{\mathrm{H}_{2} \mathrm{O}}$ was observed in one (Figure 5) and inhibition of nicotine antidiuresis was clearly apparent in both.

Acute decreases in $\mathrm{C}_{\mathrm{cr}}$ were observed during the antidiuretic responses to nicotine, vasopressin and hypertonic saline in several control studies and were less apparent for similar periods in steroid studies. Since sudden changes in urinary flow result in unavoidable errors in calculation of clearances, mean $\mathrm{C}_{\mathrm{cr}}$ values were determined for each period to include the time from onset of oliguria to the return of water diuresis. These values were compared with the mean $\mathrm{C}_{\mathrm{cr}}$ observed during water diuresis in each study as well as for similar periods in control and steroid studies.

Nicotine produced an average change in mean $\mathrm{C}_{\mathrm{er}}$ of -2 per cent in four control studies and +1 per cent in four steroid studies. Vasopressin resulted in an average fall in mean $\mathrm{C}_{\mathrm{er}}$ of 7 and 10 per cent, and hypertonic saline a decrease of 24 and 26 per cent, respectively, in two control and in two steroid studies, but the observations were too few for valid conclusions.

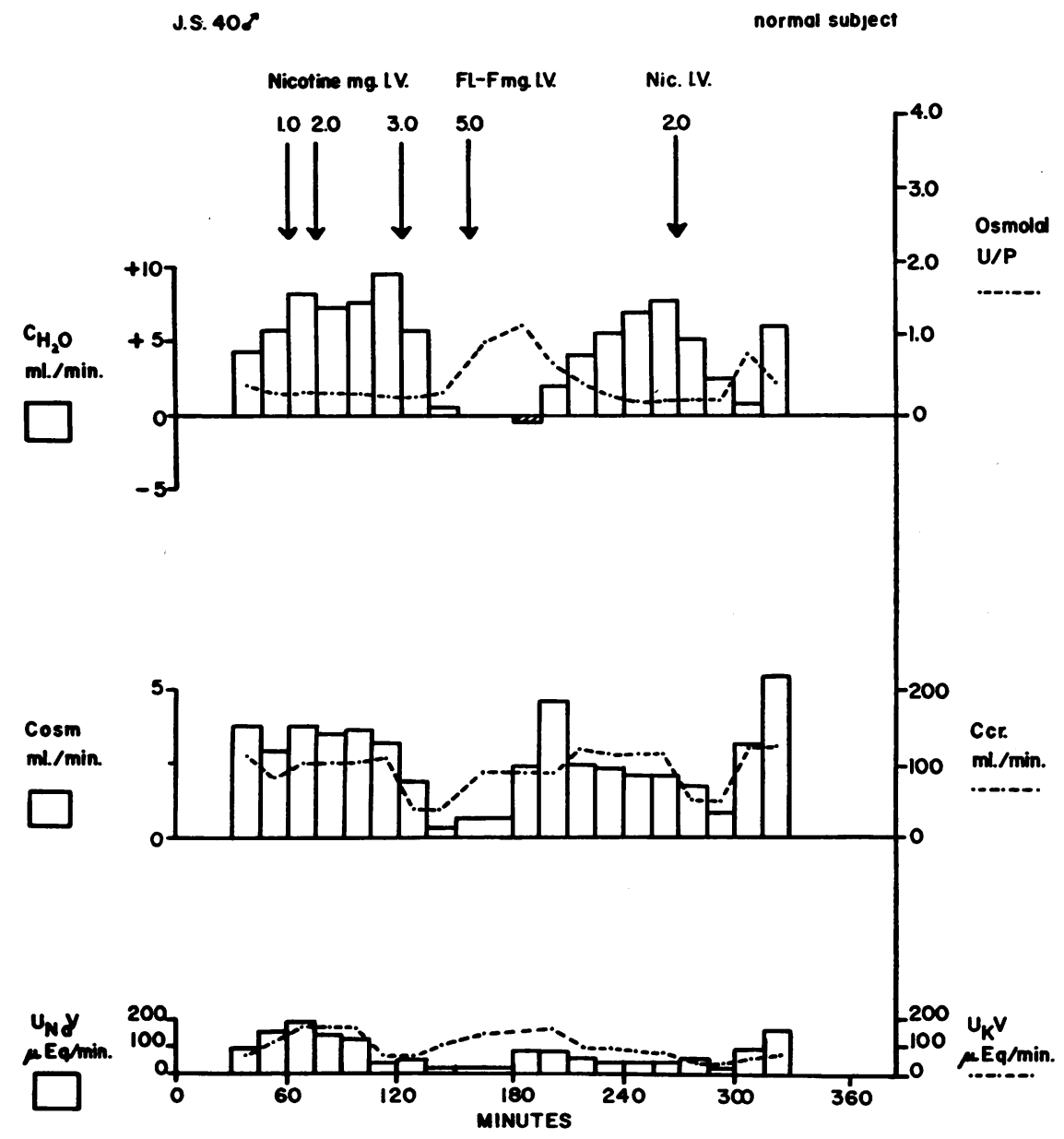

Fig. 6. EFfect of Fluorocortisol on Antidiuretic Response to Nicotine. Sustained hydration of $1.0 \mathrm{~L}$. 


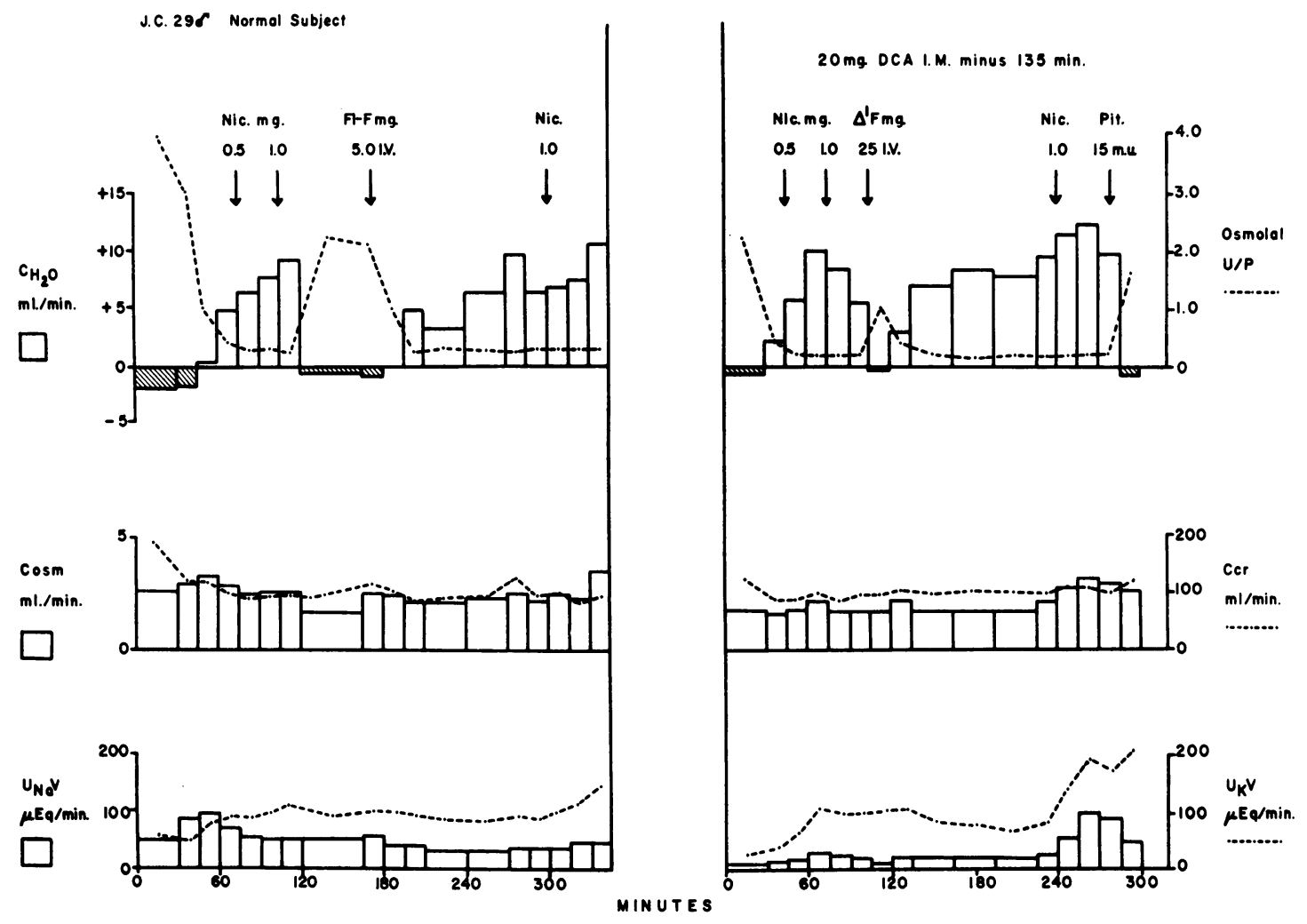

Fig. 7. Effect of adrenal steroids on antidiuretic response to nicotine. Sustained hydration of $1.0 \mathrm{~L}$; $\Delta^{\prime} \mathrm{F}=$ prednisolone.

Steroid therapy by itself resulted in an average increase in $\mathrm{C}_{\mathrm{cr}}$ of only 3 per cent in the four subjects studied.

3. Effect of fuorocortisol (Fl-F) in normal subjects. Two subjects showed depression of the antidiuretic effect of nicotine with administration of Fl-F (Table I, Figures 2 and 7). However, this steroid enhanced the antidiuretic response to a standard dose of nicotine in a third subject (Figure 5) and actually decreased the effective antidiuretic dose of nicotine in another (Figure $6)$. In the latter subject, the toxic effects of nicotine on the central nervous system (dizziness, nausea) were also markedly accentuated.

Marked $\mathrm{Na}$ retention, associated with a decrease in minimum $\mathrm{U}_{\text {osm }}$ during diuresis was observed in three of these subjects. A distinct increase in $\mathrm{C}_{\mathrm{II}_{2} \mathrm{O}}$ was apparent, however, only in the one subject who showed the most pronounced suppression of nicotine effect (Table I).

Acute changes in $\mathrm{C}_{\mathrm{cr}}$ were also evident with administration of nicotine in several of these studies. Calculation of mean $\mathrm{C}_{\mathrm{er}}$ values as previously described, however, revealed average decreases of only 6 and 4 per cent, respectively, for control and steroid studies, and the steroid itself produced only a slight rise of 7 per cent in mean $\mathrm{C}_{\mathrm{cr}}$ in comparison to control diuresis values.

4. Effects of DCA in normal subjects. Large doses of DCA administered prior to constant hydration resulted in marked $\mathrm{Na}$ retention and suppression of nicotine antidiuresis in two subjects (Table I, Figures 2 and 7 ). Although the onset of water diuresis was more rapid in both, $\mathrm{C}_{\mathrm{H}_{2} \mathrm{O}}$ was increased only in Subject J.C., who also showed a definite fall in total solute excretion. Changes in mean $\mathrm{C}_{\mathrm{cr}}$ during nicotine antidiuresis equalled -11 and -14 per cent in the control studies and +2 and -6 per cent in the DCA studies.

5. Effect of glucocorticoids in Addison's disease. Control studies performed in three patients with Addison's disease off cortisone therapy for periods of 1 to 3 days revealed relatively normal patterns of water diuresis in two patients (Figures 8,9 and 10) and marked depression of diu- 
resis in a third (Figure 11). One of the former patients evidenced a normal antidiuretic response to nicotine (Figure 8), but the other showed increased sensitivity of the neurohypophysis to stimuli, with definite "neural" stimulation of vasopressin release apparent with as little as $0.5 \mathrm{mg}$ nicotine (Figure 9) as well as with a relatively trivial painful stimulus elicited by manipulation of an indwelling intravenous needle (Figure 10). Sensitivity of the osmotic control of vasopressin release was also apparent in this patient, as evidenced by a substantial antidiuretic response with administration of as little as $5 \mathrm{ml}$ of 3 per cent $\mathrm{NaCl}$ per $\mathrm{kg}$ (Figure 10); however, the antidiuretic effect of vasopressin was found to be within normal limits (Figure 9). The patient with the depressed diuresis showed a prolonged antidiuretic response to $0.5 \mathrm{mg}$ nicotine associated with a rise in $\mathrm{U}_{\mathrm{osm}}$ only to the isosmotic level.

Twenty-five to $50 \mathrm{mg}$ cortisone administered by mouth within several hours of hydration resulted in greater urinary hypotonicity, enhanced free water diuresis, and depression of the antidiuretic effect of nicotine in each patient (Figures 8,11 and 12). Intravenous administration of 25 mg prednisolone, a glucocorticoid four to five times more potent than cortisone, resulted in much higher levels of water diuresis and greater suppression of the antidiuretic effect of nicotine than had been observed with similar doses of oral cortisone in two patients (Figures 8 and 11). The antidiuretic effects of vasopressin and hypertonic saline were essentially unaltered by cortisone therapy in one patient so studied (Figure 12).

A substantial increase in $\mathrm{Na}$ and total solute excretion accompanied the enhanced water diuresis observed during cortisone therapy in two patients (Figures 8 and 12). Mean $\mathrm{C}_{\mathrm{cr}}$ showed a substantial decrease of 35,39 and 48 per cent with administration of nicotine, vasopressin and hypertonic saline, respectively, during the control studies in Patient M.R. (Figures 9 and 10). Less pronounced decreases of 14, 26 and 33 per

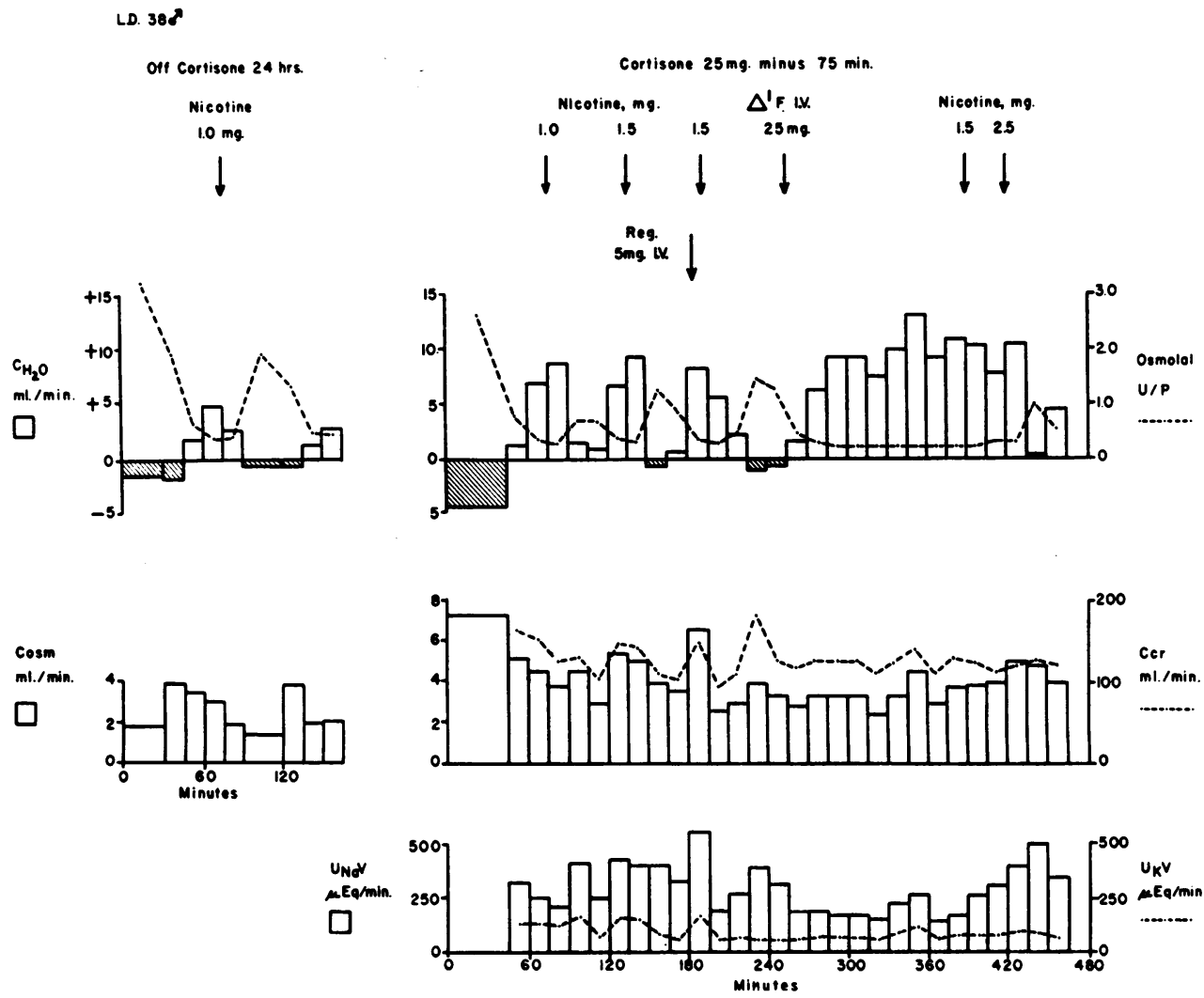

Fig. 8. EFfect of adrenal steroids on nicotine antidiuresis in Addison's disease. Sustained hydration of $1.0 \mathrm{~L}$; Reg. = phentolamine (Regitine) i.v. 

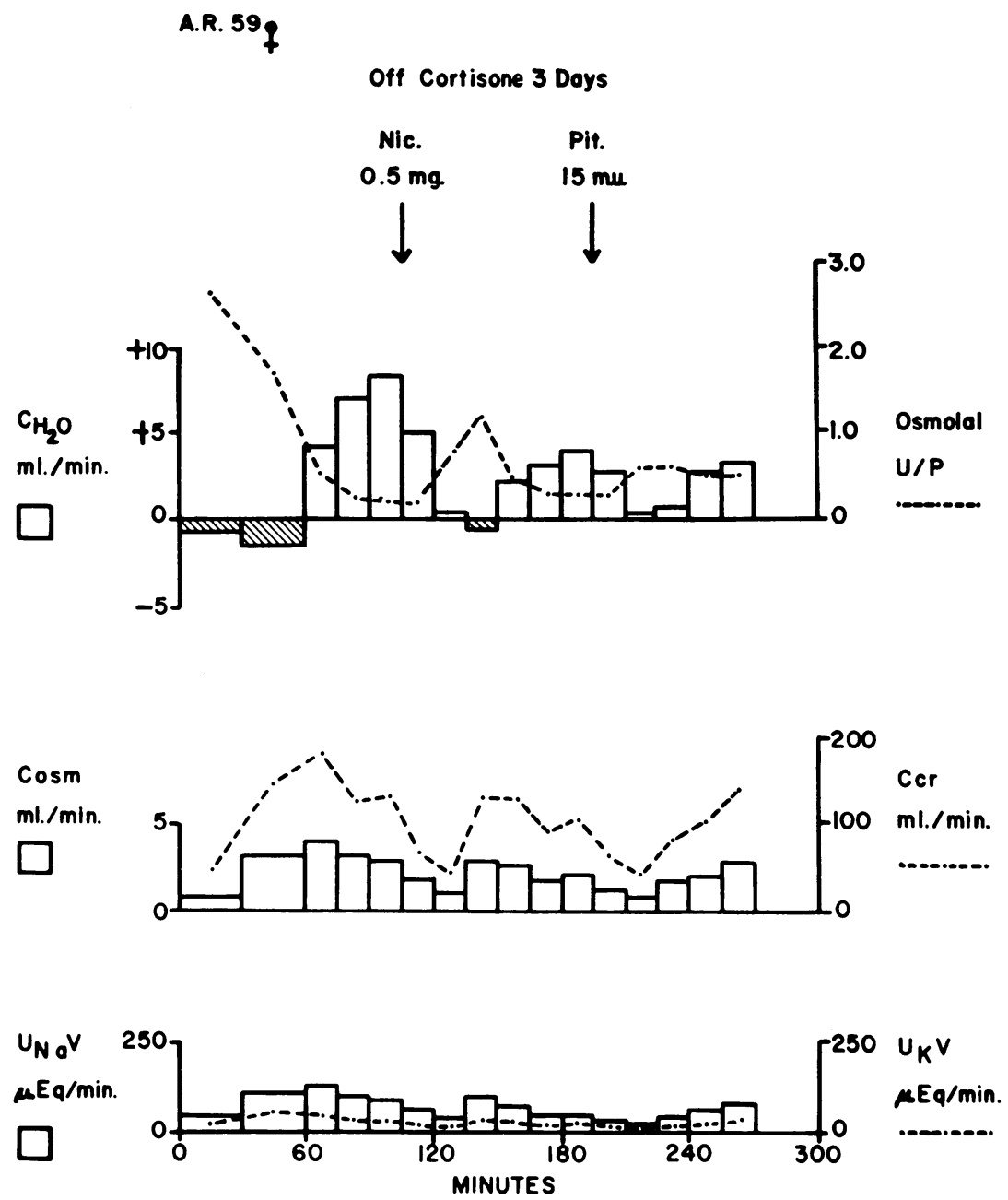

Fig. 9. Antidiuretic effect of nicotine and vasopressin in Addison's disease. Sustained hydration of $1.2 \mathrm{~L}$.

cent, respectively, appeared during the study with cortisone (Figure 12).

\section{DISCUSSION}

These studies have shown fairly consistent effects of cortisol-like steroids on water metabolism in man; these include shortening of the delay time in onset of water diuresis, greater dilution of the urine, and increased free water excretion both in normal and Addisonian subjects studied under conditions of standard hydration (Table II). Simultaneously, the glucocorticoids consistently elevated the threshold dose of nicotine for stimulation of vasopressin release. The neurohypophyseal response to induced hypertonicity and the anticliuretic effect of exogenous vasopres- sin, however, were not suppressed by steroids or masked by the sodium and solute diuresis which occasionally occurred with glucocorticoid administration.

There is good evidence that nicotine stimulates release of vasopressin from the neurohypophysis (12), probably by an acetylcholine-like action of the drug (13) ${ }^{5}$ on the supraoptic neurones of the

5 The fact that vasopressin release with nicotine was apparent in three patients with primary adrenocortical insufficiency, who often demonstrate atrophy or destruction of the adrenal medullae as well, suggests that the antidiuretic action of nicotine in man is not mediated through release of epinephrine. The failure of phentolamine to suppress nicotine antidiuresis in one patient was evidence against an effect of circulating sympathomimetic amines on neurohypophyseal secretion. 
hypothalannus, resulting in release of vasopressin stored in the posterior lobe of the pituitary body into the systemic circulation.

Hypertonicity of the body fluids also promotes release of vasopressin (14), but there are some studies in man (15) and $\operatorname{dog}(16)$, and theoretical considerations (17) to suggest that the osmoregulatory response may not be mediated through the same pathways to the neurohypophysis as nicotine.

The results of the present study are compatible with the hypothesis that glucocorticoids suppress the response of the supraoptic neurones of the hypothalamus to neural stimuli without altering the osmotic control of vasopressin release. Corroborative evidence for inhibitory actions of glucocorticoids on hypothalamic neurosecretion is their rapid effect on $\mathrm{ACTH}$ release (18), which may be through suppression of secretion of corticotropin-releasing factor from the hypothalamus (19).

Since preliminary publication of portions of these clata (4-7), Gaunt, Lloyd and Chart (20) reported an increase in neurosecretory material in the posterior pituitaries of rats treated with cortisol, compatible with a suppressive action of

A.R. $59 q$

Off Cortisone 3 Days
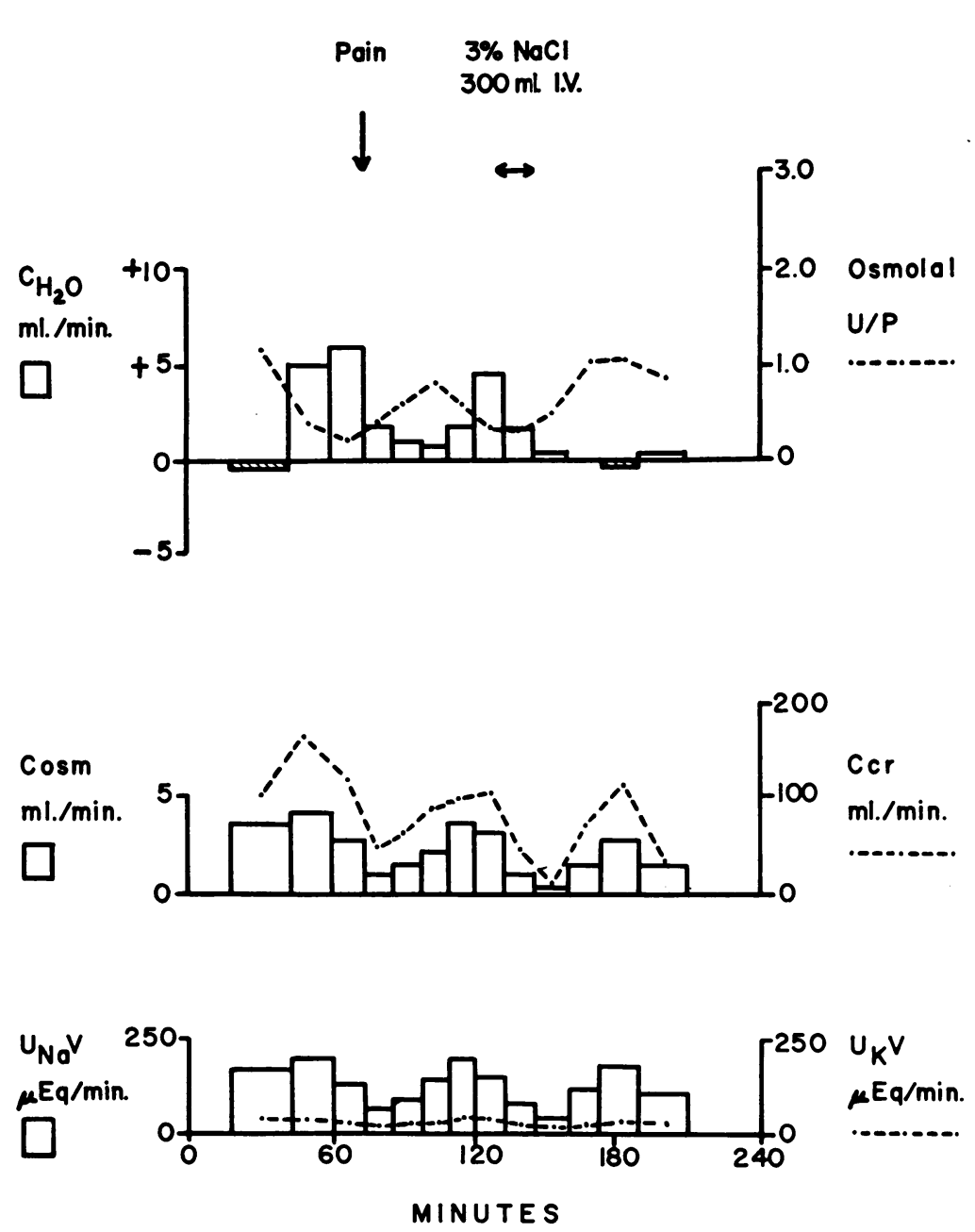

Fig. 10. EFFect of PAIN AND hypertonic saline on vasopressin Release in Apprson's disease. Sustained hydration of $1.2 \mathrm{~L}$. 

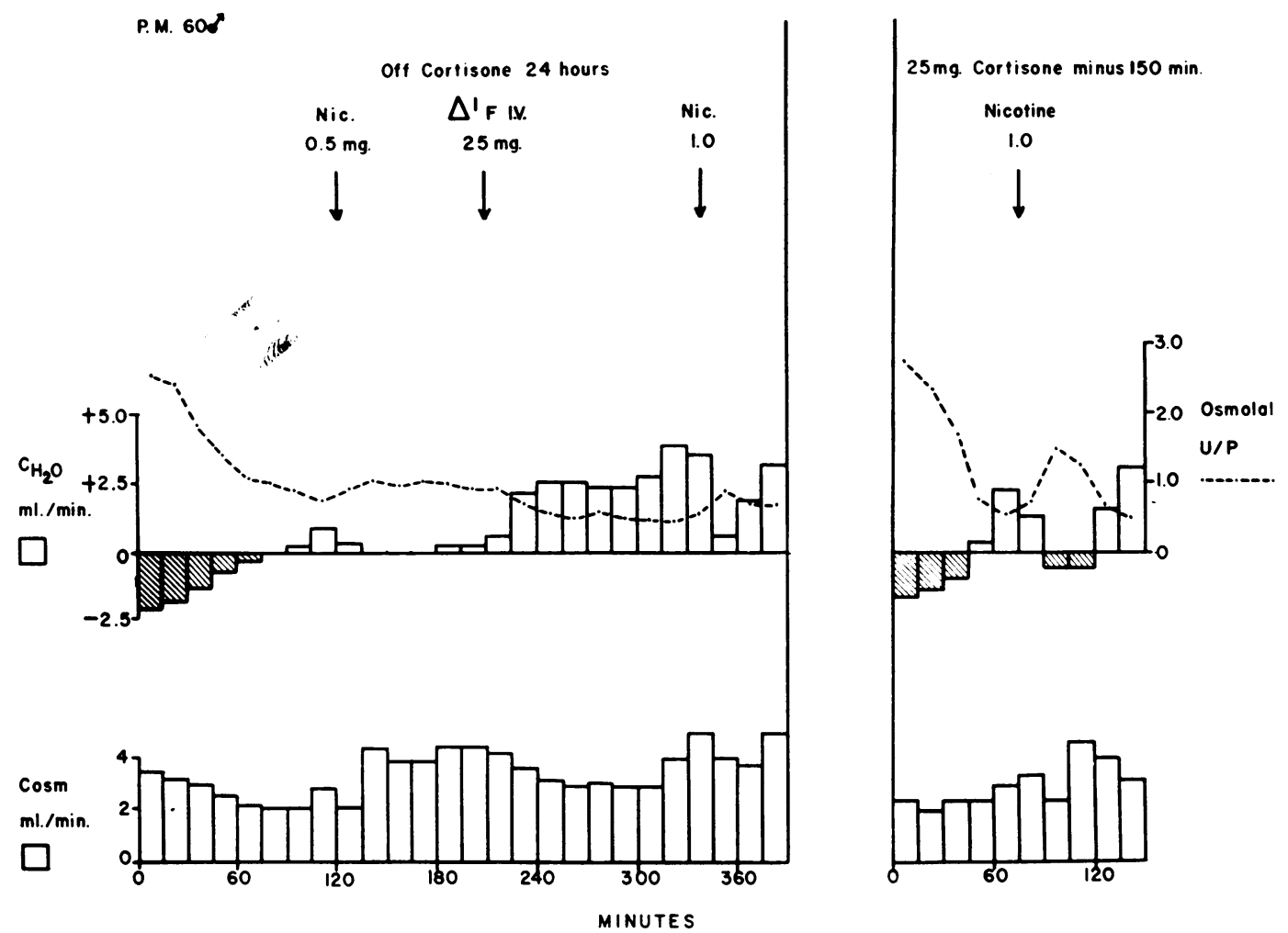

Fig. 11. Effect of adrexal steroids on nicotine antidiuresis in Addson's disease. Sustained hydration of $1.0 \mathrm{~L}$.

this steroid on vasopressin release, and McCann, Fruit and Fulford (21), and de Wied and Mirsky (22) have shown that glucocorticoids rapidly block the antidiuretic response to nicotine and to other stressful stimuli in the rat. These results provide experimental evidence from other laboratories to corroborate our findings in man.

These studies suggest a possible explanation for the abnormal water diuresis of adrenocortical insufficiency which is related to an antidiuretic mechanism not under the control of extracellular fluid osmotic pressure (23). The neurohypophysis probably is overly sensitive to stimuli in the absence of glucocorticoids, and increased sensitivity to the antidiuretic effects of nicotine has been demonstrated previously in hypophysectomized patients (24) and in patients with spontaneous pan-hypopituitarism $(3,25)$ as well as in the Addisonian subjects in this report. Many studies have shown that neural and vascular (ischemic) stimuli readily supersede the relatively weak inhibitory effect of plasma hypotonicity on vasopressin release (17). An inhibitory effect of glucocorticoids on the responsiveness of the supraoptic nuclei to such stimuli may normalize neurohypophyseal function and permit adequate suppression of vasopressin release from the posterior lobe by hemodilution and a normal diuretic response to hydration. The observations of Porter (26) that adrenal steroids suppress both spontaneous electrical activity and the excitatory effects of epinephrine on the hypothalamus in adrenalectomized monkeys provides some experimental evidence for this theory.

The fact that normal subjects demonstrate similar suppression of neurohypophyseal response to nicotine with steroid therapy, usually associated with enhanced free water diuresis exceeding previously established maxima, suggests that vasopressin secretion may not be inhibited completely by water administration even in normal man. This possibility interjects a cautious note in the interpretation of studies performed during water diuresis based upon the assumption that circulating vasopressin has been completely removed from the experimental protocol. 

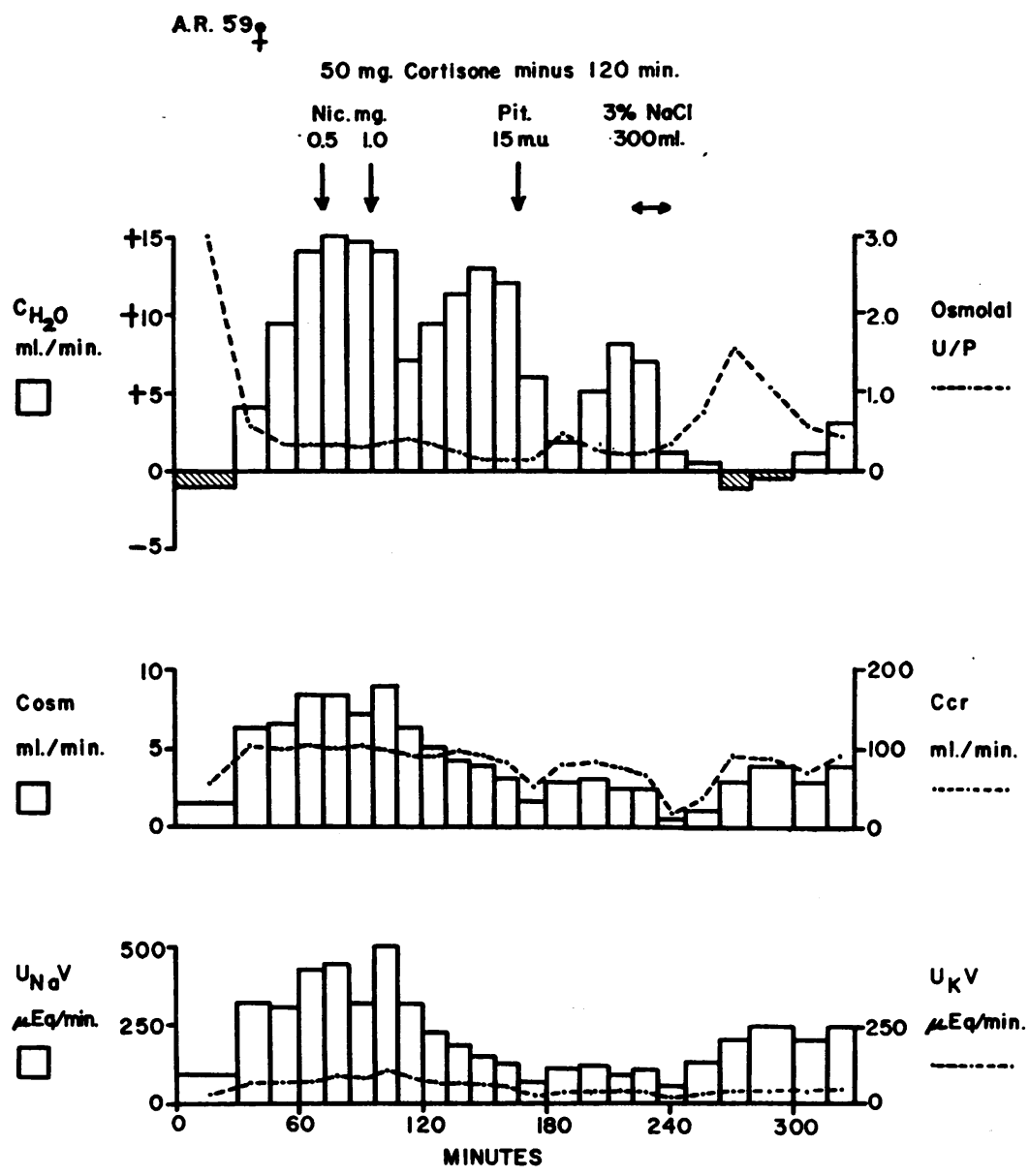

Fig. 12. EFFECT OF CORTISONE ON NEUROHYPOPHySEAL FUNCTION IN AdDison's DISEASE. Sustained hydration of $1.2 \mathrm{~L}$.

The observation of a dual action of fluorocorti- also possesses greater glucocorticoid effects than sol on vasopressin release mechanisms was of par- aldosterone (27), which could result in a cortisolticular interest. This steroid is as potent as al- like action on neurohypophyseal secretion. The dosterone in its effect on mineral metabolism, but occasional enhancement of the neurohypophyseal

TABLE II

Summary of effects of adrenal streoids in normal and Addisonian subjects *

\begin{tabular}{|c|c|c|c|c|c|c|c|c|c|c|c|c|c|c|}
\hline \multirow[b]{2}{*}{ Group } & \multirow[b]{2}{*}{ Steroid } & \multirow{2}{*}{$\begin{array}{l}\text { No. of } \\
\text { studies }\end{array}$} & \multicolumn{3}{|c|}{$\mathrm{C}_{\mathrm{H}, \mathrm{O}}$} & \multicolumn{3}{|c|}{$\mathrm{U}_{\mathrm{osm}}$} & \multicolumn{3}{|c|}{$\mathrm{C}_{\mathrm{osm}}$} & \multicolumn{3}{|c|}{$\begin{array}{l}\text { Nicotine } \\
\text { threshold }\end{array}$} \\
\hline & & & Inc. & Decr. & $\overline{\text { Same }}$ & Inc. & Decr. & Same & Inc. & Decr. & Same & Inc. & Decr. & Same \\
\hline $\begin{array}{l}\text { Normal } \\
\text { subjects }\end{array}$ & $\begin{array}{l}F \\
F 1-F \\
D C A\end{array}$ & $\begin{array}{l}6 \\
4 \\
2\end{array}$ & $\begin{array}{l}6 \\
1 \\
1\end{array}$ & $\begin{array}{l}0 \\
2 \\
0\end{array}$ & $\begin{array}{l}0 \\
1 \\
1\end{array}$ & $\begin{array}{l}1 \\
0 \\
0\end{array}$ & $\begin{array}{l}4 \\
2 \\
1\end{array}$ & $\begin{array}{l}1 \\
2 \\
1\end{array}$ & $\begin{array}{l}3 \\
0 \\
1\end{array}$ & $\begin{array}{l}2 \\
4 \\
1\end{array}$ & $\begin{array}{l}1 \\
0 \\
0\end{array}$ & $\begin{array}{l}6 \\
2 \\
1\end{array}$ & $\begin{array}{l}0 \\
1 \\
0\end{array}$ & $\begin{array}{l}0 \\
1 \\
1\end{array}$ \\
\hline $\begin{array}{l}\text { Addison's } \\
\text { disease }\end{array}$ & $\mathrm{F}$ & 5 & 5 & 0 & 0 & 1 & 4 & 0 & 2 & 2 & 1 & 4 & 0 & 0 \\
\hline
\end{tabular}

${ }^{*} \mathrm{~F}=$ cortisol-like steroids, $\mathrm{F} 1-\mathrm{F}=$ fluorocortisol, $\mathrm{DCA}=$ desoxycorticosterone acetate, inc. = increase, decr. = decrease

$\dagger$ Nicotine threshold refers to the dose of intravenous nicotine required to produce an unequivocal decrease in $\mathrm{C}_{\mathrm{H}_{2} \mathrm{O}}$ and rise in $U_{\text {osm. }}$. 
response to nicotine by $\mathrm{Fl}-\mathrm{F}$, however, suggests that potent mineralocorticoids actually may increase the sensitivity of vasopressin release mechanisms in some instances, an action which may be of fundamental importance in the endocrine regulation of the volume and tonicity of the body fluids. The observation that DCA exerted a glucocorticoid-like action on neurohypophyseal function in two normal subjects is difficult to explain within the framework of this hypothesis. Since both subjects showed similar responses to Fl-F, and since DCA is known to produce extremely variable effects on electrolyte and water metabolism in normal subjects, similar variability in the action of mineralocorticoids on neurohypophyseal function in normal man should not be too surprising.

There is ample evidence to show that marked alterations in total solute excretion mask the action of vasopressin on renal tubular reabsorption of water. Although increased sodium and total solute excretion were occasionally observed with administration of cortisol-like steroids in this study, there were sufficient data showing definite suppression of nicotine antidiuresis during periods of constant sodium and total solute excretion, without apparent alteration in the intensity or duration of the antidiuretic response to hypertonic saline or exogenous vasopressin, to corroborate the conclusion that the glucocorticoids suppress nicotine-induced vasopressin release. Further substantiation of this conclusion was apparent in several studies in which marked and sustained sodium retention was produced initially by a potent mineralocorticoid following which glucocorticoid administration clearly suppressed nicotine antidiuresis without altering the depressed rates of sodium and solute excretion or the effects of hypertonic saline and vasopressin.

The hypothesis that glucocorticoids suppress vasopressin release does not deny other possible actions of adrenal steroids on water diuresis, such as that associated with increases in renal hemodynamics (28), but only slight effects of steroids on glomerular filtration rate $\left(\mathrm{C}_{\mathrm{cr}}\right)$ were observed in this study. The acute decreases in $\mathrm{C}_{\mathrm{cr}}$ frequently apparent in this study during nicotine antidiuresis suggest a possible effect of nicotine on the vascular system and the renal circulation which could explain the increased tubular reabsorption of water without implicating a role of vasopressin release in this phenomenon. However, mean creatinine clearances for the entire periods of nicotine antidiuresis were found to be relatively constant except in one patient with Addison's disease, and this lack of effect of nicotine on glomerular filtration rate has also been observed by others (29).

A conclusion that the adrenal steroids exert a direct effect on permeability of renal tubular cells to water (2) also would have been tenable in interpretation of our data if studies of neurohypophyseal function had not been performed simultaneously with measurements of free water clearance. The definite association between acute increases in free water excretion and marked alterations in neurohypophyseal secretory mechanisms provides circumstantial evidence to favor a causal relationship between the two phenomena. Further clarification of this hypothesis must await actual measurement of vasopressin levels in the plasma during adrenal steroid administration.

\section{SUMMARY}

The effect of various adrenal steroids on standard water diuresis and on the antidiuretic response to vasopressin, nicotine and hypertonic saline has been evaluated in normal and in Addisonian subjects. Glucocorticoids regularly suppress the neurohypophyseal response to intravenous nicotine without altering release of vasopressin produced by infusion of hypertonic saline or the antidiuretic effects of exogenous vasopressin. In several instances the salt-retaining hormone, fluorocortisol, has been shown to sensitize the response of the neurohypophysis to nicotine.

The data suggest that glucocorticoids enhance water diuresis in normal and in Addisonian subjects by inhibiting the hypothalamic control of vasopressin release, rather than by competition with vasopressin at the renal tubular level.

\section{REFERENCES}

1. Gaunt, R., Birnie, J. H., and Eversole, W. J. Adrenal cortex and water metabolism. Physiol. Rev. 1949, 29, 281.

2. Raisz, L. G., McNeely, W. F., Saxon, L., and Rosenbaum, J. D. The effects of cortisone and hydrocortisone on water diuresis and renal function in man. J. clin. Invest. 1957, 36, 767.

3. Dingman, J. F., Despointes, R. H., Laidlaw, J. C., and Thorn, G. W. Studies of neurohypophyseal 
function in man: Effect of adrenal steroids on polyuria in combined anterior and posterior pituitary insufficiency. J. Lab. clin. Med. 1958, 51, 690.

4. Dingman, J. F., and Thorn, G. W. Cortisone inhibition of $\mathrm{ADH}$ secretion from the neurohypophysis (abstract). J. clin. Endocr. 1955, 15, 871.

5. Dingman, J. F., and Despointes, R. H. Hypothalamic action of adrenal steroids (abstract). J. clin. Endocr. 1956, 16, 936.

6. Dingman, J. F., and Despointes, R. H. Adrenal steroids and water metabolism (abstract). J. clin. Invest. 1957, 36, 882.

7. Dingman, J. F., and Despointes, R. H. Unpublished data quoted by Gaunt, R., Lloyd, C. W., and Chart, J. J. in Reference 20.

8. Dingman, J. F., Benirschke, K., and Thorn, G. W. Studies of neurohypophyseal function in man. Diabetes insipidus and psychogenic polydipsia. Amer. J. Med. 1957, 23, 226.

9. Bonsnes, R. W., and Taussky, H. H. On colorimetric determination of creatinine by Jaffé reaction. J. biol. Chem. 1945, 158, 581.

10. Wesson, L. G., Jr., and Anslow, W. P., Jr. Effect of osmotic and mercurial diuresis on simultaneous water diuresis. Amer. J. Physiol. 1952, 170, 255.

11. Burn, G. P., and Grewal, R. S. The antidiuretic response to and excretion of pituitary (posterior lobe) extract in man, with reference to the action of nicotine. Brit. J. Pharmacol. 1951, 6, 471.

12. Burn, J. H., Truelove, L. H., and Burn. I. The antidiuretic action of nicotine and of smoking. Brit. med. J. 1945, 1, 403.

13. Pickford, M. The inhibitory effect of acetylcholine on water diuresis in the dog, and its pituitary transmision. J. Physiol. (Lond.) 1939, 95, 226.

14. Verney, E. B. Absorption and excretion of water; antidiuretic hormone. Lancet 1946, 2, 739 and 781.

15. Dingman, J. F. Selective failure of osmoreceptor function as a cause of diabetes insipidus. Fed. Proc. 1954, 13, 36.

16. Verney, E. B. Renal excretion of water and salt. Lancet 1957, 2, 1237 and 1295.

17. Dingman, J. F. Hypothalamus and the endocrine control of sodium and water metabolism in man. Amer. J. med. Sci. 1958, 235, 79.

18. Bethune, J. E., Nelson, D. H., and Thorn, G. W. Plasma adrenocorticotrophic hormone in Addison's disease and its modification by the administration of adrenal steroids. J. clin. Invest. 1957, 36, 1701.

19. Saffran, M., Schally, A. V., and Benfey, B. G. Stimulation of the release of corticotropin from the adrenohypophysis by a neurohypophysial factor. Endocrinology 1955, 57, 439.

20. Gaunt, R., Lloyd, C. W., and Chart, J. J. The adrenalneurohypophysial interrelationship in The Neurohypophysis, H. Heller, Ed. New York, Academic Press, 1957, p. 233.

21. McCann, S. M., Fruit, A., and Fulford, B. D. Studies on the loci of action of cortical hormones in inhibiting the release of adrenocorticotrophin. Endocrinology 1958, 63, 29.

22. deWied, D., and Mirsky, I. A. The action of $\Delta^{\prime}$ hydrocortisone on the antidiuretic and adrenocorticotropic responses to noxious stimuli. Endocrinology 1959, 64, 955.

23. Leaf, A., and Mamby, A. R. An antidiuretic mechanism not regulated by extracellular fluid tonicity. J. clin. Invest. 1952, 31, 60.

24. Dingman, J. F., Jessiman, A. G., Despointes, R. H., Hammond, W. G., Matson, D. D., Emerson, K., Jr., and Moore, F. D. Residual neurohypophyseal function in hypophysectomized man. New Engl. J. Med. 1959, 260, 997.

25. Gaitan, E., and Dingman, J. F. Hypothalamicpituitary regulation of water metabolism in man (abstract). Proc. Endocr. Soc. June 1959, no. 114.

26. Porter, R. W. The central nervous system and stressinduced eosinopenia. Recent Progr. Hormone Res. 1954, 10, 1.

27. Thorn, G. W., Renold, A. E., Morse, W. I., Goldfien, A., and Reddy, W. J. Highly potent adrenal cortical steroids: Structure and biologic activity. Ann. intern. Med. 1955, 43, 979.

28. Kleeman, C. R., Maxwell, M. H., and Rockney, R. E. -Mechanisms of impaired water excretion in adrenal and pituitary insufficiency. I. The role of altered glomerular filtration rate and solute excretion. J. clin. Invest. 1958, 37, 1799.

29. Sinclair-Smith, B. C., Sisson, J., Kattus, A. A., Genecin, A., Monge, C., McKeever, W., and Newman, E. V. The effects of posterior pituitary extract and smoking on water, sodium and chloride excretion in normal subjects and in patients with congestive cardiac failure. Bull. Johns Hopk. Hosp. 1950, 87. 221. 